\title{
Suicide attempts by exogenous intoxication among female adolescents treated at a reference hospital in the city of Recife-PE, Brazil
}

\author{
Tentativas de suicídio por intoxicação exógena em adolescentes do sexo feminino atendidas \\ em um hospital de referência de Recife-PE, Brasil \\ Tentativas de suicidio por intoxicación exógena de adolescentes del sexo femenino atendidas \\ en un hospital de referencia en la ciudad de Recife-PE, Brasil
}

\section{Juliana Lourenço de Araújo Veras', Cintia Regina Tornisiello Katz"}

' Universidade de Pernambuco, Faculdade de Odontologia, Programa de Pós-Graduação em Hebiatria. Recife-PE, Brasil. " Universidade de Pernambuco, Faculdade de Odontologia, Programa de Pós-Graduação em Odontologia, Programa de Pós-Graduação em Hebiatria. Recife-PE, Brasil.

Submissão: 18-11-2010 Aprovação: 20-12-2011

\begin{abstract}
This study aimed to assess cases of self-inflicted poisoning among adolescents reported by the Toxicological Care Center of a reference hospital in Recife-PE, Brazil. The data were collected between March and May 2010 from hospital charts and structured interviews with the participants and parents/guardians. Among the 25 cases of attempted suicide registered in the period, 21 were female adolescents, who made up the sample of the present study. The adolescents were between 13 and 19 years of age. Pesticides were the most frequent toxic agent used (61.9\%). The results of the present study underscore the importance of studying suicide in this population, with a focus on family relations, in order to lay the foundation for the development of prevention and treatment programs for this vulnerable group.
\end{abstract}

Key words: Suicide; Suicide Attempt; Poisoning; Adolescence; Toxic Substances

\section{RESUMO}

Este estudo objetivou avaliar os casos de intoxicação exógena ocorridos em adolescentes notificados pelo Centro de Assistência Toxicológica de um hospital de Recife/PE. Trata-se de um estudo preliminar, exploratório, realizado no período de março a maio de 2010. Dos 25 casos de tentativas de suicídio notificados no período estudado, 21 eram de adolescentes do sexo feminino, que compuseram a amostra. Observou-se que as adolescentes apresentavam idades entre 13 e 19 anos. A intoxicação exógena pelo uso de praguicidas foi a mais freqüente (61,9\%). Esses resultados chamam a atenção para a importância do estudo do suicídio nesta população, sobretudo com enfoque nas relações familiares, para embasar o desenvolvimento de programas de prevenção e tratamento para este grupo mais vulnerável.

Descritores: Suicídio; Tentativa de suicídio; Envenenamento; Adolescência; Substâncias tóxicas.

\section{RESUMEN}

El objetivo de este estudio ha sido evaluar los casos de intoxicación exógena involucrando muchachas adolescentes, registrados por el Centro de Atención Toxicológica de un hospital de Recife/PE, Brasil. Se trata de un estudio preliminar, exploratorio, realizado entre los meses de marzo y mayo de 2010. Del total de 25 (veinticinco) casos de tentativas de suicidio registrados en el período investigado, 21 (veintiuno) se referían a adolescentes del sexo femenino, los cuales han compuesto la muestra. Se ha observado que las edades de las jóvenes variaban de los 13 (trece) a los 19 (diecinueve) años. La intoxicación exógena resultante del uso de plaguicidas fue la más frecuente: $61.9 \%$ (sesenta y uno punto nueve por ciento). Tales resultados ponen de relieve la importancia del estudio del suicidio en el seno de ese grupo poblacional, volcándose la atención hacia las relaciones familiares, con miras a la creación/implantación de programas de prevención y tratamiento destinados a esa capa más vulnerable de la población.

Palabras clave: Suicidio; Tentativa de suicidio; Envenenamiento; Adolescencia; Substancias tóxicas. 


\section{INTRODUCTION}

Adolescence is described as a transition phase of human development between childhood and adulthood occurring in the second decade of life. This phase is mainly characterized by the biological transformations of puberty related to bio-psychosocial maturation. Adolescents search for themselves and an identity, with progressive independence from their parents, greater ties to peer groups, sexual evolution, attitudes of social claims, mood swings and successive contradictions ${ }^{(1,2)}$.

These transformations are essential to the life of an individual and identify adolescence as a critical period subject to crises due to the fact that it is guided by moments of definitions of sexual and professional identity and values. Such transformations are often considered pathological ${ }^{(2)}$.

Adolescence may also be marked by risk behavior originating from the need to experience the new and challenge danger. The tendency to act impulsively as a form of resolving a crisis may lead adolescents to make choices without considering the possibility of causing harm to themselves or others in the present or future ${ }^{(1)}$.

The literature points to adolescence as a phase with the high rate of suicide attempts. The highest frequency of suicide attempts occurs among those between 15 and 19 years of age, especially among females, for whom the frequency is twice as high as that among males. There is a consensus that the mean age of individuals having attempted suicide has lowered in recent decades, indicating that society offers few prospects for the young population. As an attempted suicide can culminate in the complete act, it is important to consider that half of the teenagers who kill themselves had a history of previous attempts ${ }^{(3,4,5,6)}$.

Suicide among young people is a current problem in both Brazil and the world and is associated to individual, environmental and social factors. The frequency of self-destructive behavior among adolescents is a challenge to society as a whole and public healthcare professionals in particular ${ }^{(1,7)}$.

According to data from the World Health Organization, more than one thousand people of all cultures, religions, ethnic backgrounds and socioeconomic levels commit suicide in the world each day ${ }^{(8)}$. The predisposing factors in the determination of suicide include alcohol and drug abuse, physical and/or sexual violence, social isolation, psychical disorders such as depression, schizophrenia and feelings of despair, availability of means for committing suicide and poor health ${ }^{(6,9)}$.

According to a number of authors, the female gender is more susceptible to suicide attempts due to the fact that females are more vulnerable to changes in the transition to adulthood and are more subject to mistreatment at home, often suffering prejudiced notions on the part of society and other factors that can lead to depression and mental illness ${ }^{(10)}$.

Suicide attempts are closely related to life crises and frustrating experiences ${ }^{(11)}$. Especially for the female gender, adolescence is the characteristic period for the initiation into emotional/romantic relationships, which is also a factor of considerable importance in the generation of conflict and frustration and may predispose an individual to attempting suicide $^{(7)}$. Suicide is a continuous process the goes from conception and its different forms of expression, passing through threats, gestures and intentions until reaching the act itself. Any of these elements should be considered a risk factor for suicide $^{(12)}$.

In a study carried out on the main capital cities of Brazil, the cities of Porto Alegre, Curitiba and Belém had the highest suicide rates among young people and gender differences were detected. One study reports an increase in the suicide rate in the state of Pernambuco between 1990 and 1995, with a slight decline in 1998; the same study found that males committed suicide more, whereas females had a greater number of suicide attempts ${ }^{(13)}$.

The preponderance of suicide attempts among female youths does not imply that the same process occurs among males. According to a number of authors, a possible explanation for this is that, when frustration occurs in a relationship, women tend to cause harm to themselves, whereas men tend to react aggressively toward others ${ }^{(14)}$. Other authors state that suicide is an act with a more final nature for men than for women. While men seek an immediate solution in the extreme act of suicide for their interpersonal crises, especially in the socioeconomic realm, women attempt to remedy adverse conditions of an essentially emotional/romantic nature through suicide ${ }^{(15)}$.

Some authors state that the male gender is characterized by a high degree of lethality, with the most frequent methods of suicide being hanging, use of a firearm and leaping from high places. Among the female gender, there is a tendency toward self-inflicted poisoning, which allows a greater possibility of being saved ${ }^{(16,17)}$. Poisoning is a pathological manifestation caused by toxic substances. These occurrences may be either accidental or intentional, characterizing suicide attempts, and are increasingly frequent at emergency rooms ${ }^{(18)}$.

According to the World Health Organization, the psychological impact of suicide on a family and society as a whole is immeasurable ${ }^{(19)}$. In general, a suicide affects at least six people in a family and can impact hundreds of people when occurring in a school setting or workplace. According to the American Academy of Suicidology, for each suicide among young people, there are between one and two hundred suicide attempts ${ }^{(20)}$.

Thus, the study of suicide attempts among adolescents is important, as the characterization of the population at risk could assist in the prevention and control of the physical, psychological and social harm cause by such behavior as well as the management of treatment for such cases.

\section{METHODS}

This study aimed to assess cases of exogenous intoxication among female adolescents between 12 and 19 years of age reported by the Toxicological Care Center of Pernambuco, between March and May 2010. The research received approval from the ethics committee of the Hospital da Restauração, Recife-PE, Brazil (Process Number CAEE 0139.0.102.000-09).

An exploratory, case-series study was carried out as part of 
a master's research, the aim of which was to study cases of attempted suicide and associated factors among adolescents in the city of Recife, PE (Brazil) in 2010. The study was conducted in the emergency ward of the Hospital da Restauração, which is a state public reference hospital for victims of trauma, intoxication and neurological diseases. The data were collected from hospital charts (gender, age, toxic agent and progression) and interviews with the adolescents using a structured questionnaire made up of closed questions on previous suicide attempts (prior history, time elapsed and method employed).

Parents/guardians were also interviewed to obtain information on their level of schooling, monthly household income and economic classification. For the latter variable, the Economic Classification Questionnaire of Brazil drafted by the Brazilian Association of Research Companies in 2008 was used, the aim of which is to estimate the buying power of individuals and urban families, with no attempt to categorize the population in terms of social classes, but rather exclusively in economic classes. In decreasing order of buying power, families are categorized in Classes A1, A2, B1, B2, C, D and E.

For inclusion of the adolescents in the study, parents/guardians granted authorization by signing a term of informed consent. There was no refusal on the part of any parent/guardian or adolescent to participate in the study.

The collected data was analyzed using descriptive statistics techniques in the SPSS software version 7.5.

\section{RESULTS}

In the period studied, 25 cases of attempted suicides by adolescents were registered at the Toxicological Care Center of Pernambuco, among which 21 cases were female adolescents and four were males. The present study focuses only on the female population.

Table 1 displays the data characterizing the sample. The participants had between 13 and 19 years of age, with the largest group aged 15 years. Most of the adolescents (85.7\%) reported being single. Regarding city of residence, $42.9 \%$ lived in the city of Recife. A total of $76.2 \%$ of the interviewees had a low level of schooling (incomplete elementary school). When asked whether they attended school or exercised any paid activity, $66.7 \%(n=14)$ reported that they studied and $95.2 \%(n=20)$ reported that they did not work.

Table 2 displays data characterizing the families of the adolescents. A total of $47.6 \%$ of the parents/guardians had an incomplete elementary school education. The majority of adolescents $(71.4 \%)$ belonged to families that received less than one minimum salary monthly. Based on the economic classification criteria employed, there was a predominance of economic classes C and D (42.9\% and $52.3 \%$, respectively).

Regarding the method used for the attempted suicide, pesticide was the most frequent toxic agent $(61.9 \%)$, followed by medications (38.1\%). Among the medications used for self-intoxication, psychotropic drugs were the most frequent $(62.5 \%)$. Among the 21 adolescents surveyed, 6 (31.6\%) had previously attempted suicide and the method chosen most was poisoning (Table 3).
Table 1 - Distribution of adolescents according to age, marital status, city of residence and schooling. Hospital da Restauração, Pernambuco, Brazil, 2010.

\begin{tabular}{|c|c|c|}
\hline Variables & $\mathbf{N}$ & $\%$ \\
\hline \multicolumn{3}{|l|}{ - Age (years) } \\
\hline 13 & 3 & 14.3 \\
\hline 14 & 1 & 4.8 \\
\hline 15 & 5 & 23.8 \\
\hline 16 & 3 & 14.3 \\
\hline 17 & 3 & 14.3 \\
\hline 18 & 2 & 9.5 \\
\hline 19 & 4 & 19.0 \\
\hline \multicolumn{3}{|l|}{ - Marital status } \\
\hline Single & 18 & 85.7 \\
\hline Divorced or separated & 1 & 4.8 \\
\hline Married or stable union & 2 & 9.5 \\
\hline \multicolumn{3}{|l|}{ - City of residence } \\
\hline Recife & 9 & 42.9 \\
\hline Metropolitan region of Recife & 4 & 19.0 \\
\hline Interior of the state of Pernambuco & 6 & 28.6 \\
\hline Rural zone & 2 & 9.5 \\
\hline \multicolumn{3}{|l|}{ - Schooling } \\
\hline Incomplete elementary & 16 & 76.2 \\
\hline Incomplete high school & 2 & 9.5 \\
\hline Complete high school & 1 & 4.8 \\
\hline Incomplete university & 2 & 9.5 \\
\hline TOTAL & 21 & 100.0 \\
\hline
\end{tabular}

Table 2 - Distribution of interviewees according to parents'/guardians' schooling, monthly household income and economic classification. Hospital da Restauração, Pernambuco, Brazil, 2010.

\begin{tabular}{|c|c|c|}
\hline Variables & $\mathbf{N}$ & $\%$ \\
\hline \multicolumn{3}{|l|}{ - Parents'/Guardians' schooling } \\
\hline No schooling & 4 & 19.0 \\
\hline Incomplete elementary & 10 & 47.6 \\
\hline Complete elementary & 2 & 9.5 \\
\hline Incomplete high school & 1 & 4.8 \\
\hline Complete high school & 3 & 14.3 \\
\hline Complete university & 1 & 4.8 \\
\hline \multicolumn{3}{|l|}{ - Monthly household income } \\
\hline Less than one minimum salary & 1 & 4.8 \\
\hline One minimum salary & 15 & 71.4 \\
\hline Two times the minimum salary & 3 & 14.3 \\
\hline Three times the minimum salary & 2 & 9.5 \\
\hline \multicolumn{3}{|l|}{ - Economic classification } \\
\hline Class B & 1 & 4.8 \\
\hline Class C & 9 & 42.9 \\
\hline Class D & 11 & 52.3 \\
\hline TOTAL & 21 & 100.0 \\
\hline
\end{tabular}


Table 3 - Distribution of patients according to toxic agent and type of medication used to attempt suicide. Hospital da Restauração, Pernambuco, Brazil, 2010.

\begin{tabular}{lcc}
\hline Variables & N & \% \\
\hline · Toxic agent & 8 & 38.1 \\
$\quad$ Medication & 13 & 61.9 \\
$\quad$ Pesticide & $\mathbf{2 1}$ & $\mathbf{1 0 0 . 0}$ \\
Total & & \\
\hline - Type of medication & 5 & 62.5 \\
$\quad$ Psychotropic drugs & 3 & 37.5 \\
$\quad$ Antiemetic, antihistamine, bronchodilator & $\mathbf{2 1}$ & $\mathbf{1 0 0 . 0}$ \\
Total & & \\
\hline Previous history of suicide attempt & 6 & 31.6 \\
$\quad$ Yes & 13 & 68.4 \\
$\quad$ No & $\mathbf{2 1}$ & $\mathbf{1 0 0 . 0}$ \\
Total & & \\
\hline Method employed in previous attempt & 4 & 66.6 \\
$\quad$ Exogenous intoxication/poisoning & 1 & 16.7 \\
Hanging & 1 & 16.7 \\
$\quad$ Slashing wrists & $\mathbf{6}$ & $\mathbf{1 0 0 . 0}$ \\
\hline TOTAL & & \\
\hline
\end{tabular}

\section{DISCUSSION}

In general, the results of the present study are in agreement with data reported in the literature on this topic. The majority adolescents were 15 years of age, which corroborates both national and international studies reporting an increase in the occurrence of suicide attempts among young people between 15 and 22 years of age $(22,16,13,23,1,24,21)$.

In this period, adolescents are in the post-puberty phase, in which their adult bodies are acquiring more defined forms. This is considered a period of the definition of identity and the beginning of relationships with the opposite sex, which can also generate conflict and frustration, thereby predisposing an individual to attempted suicide ${ }^{(7)}$. The author cited further states that females, especially adolescents and those with a poor economic status, attribute greater value to the establishment of emotional ties with a partner of the opposite sex, who represents security and autonomy. The consequent loss of this partner and the vulnerable, impulsive phase of adolescence are predisposing factors to attempted suicide, which contribute toward the increase in the frequency of this event among the female gender.

With regard to martial status, the vast majority of adolescents were single. This result is in agreement with findings reported in previous studies ${ }^{(7,16,25)}$.

Regarding gender differences in suicides reported in medical discourses since the $19^{\text {th }}$ century, the choices and means used are important factors to understanding the constitution of suicide between men and women. Men are said to prefer committing suicide by hanging, firearms or weapons with blades, whereas women prefer carbon monoxide asphyxiation and poisoning, seeking a "slower and sweeter" form of death ${ }^{(25,26)}$.

The results of the present study corroborate the statements of a number of authors regarding self-intoxication as the method generally used by female adolescents during a suicide attempt, involving the ingestion of medication or poisons and allowing a greater possibility of being saved ${ }^{(1,7,17,27,28)}$. Household pesticides were the most commonly used poisons, followed by medications. As reported in previous studies, these toxic substances are of easy access, which is the result of a lack of government control over the production, distribution and marketing of such products ${ }^{(16)}$.

In agreement with other studies, there was a predominance of psychotropic drugs among the cases of intoxication involving the use of medications. This finding is alarming, as this problem is further aggravated by the encouragement of selfmedication in the media, the lack of primary pharmaceutical care, the indiscriminate medical prescription of psychoactive drugs and inadequate storage in the home ${ }^{(29,16)}$.

Previous studies report that pharmaceutical substances have been the most frequent category of intentional intoxication in adolescence, especially among the female gen$\operatorname{der}^{(7,24,30)}$. However, this present study found that pesticides were the method of choice for the majority of female adolescents, although other studies have reported that the ingestion of these chemical substances and other more violent methods are more employed by the male gender ${ }^{(1,16,30)}$.

It should be stressed that the lack of information on the part of the population and healthcare professionals regarding the toxicity of chemical substances contributes to the large number of intentional intoxications in adolescence ${ }^{(16,24)}$. The recommendation of maintaining medication out of the reach of children is common. However, parents/guardians should be counseled to act in a preventive fashion so that access to medications and chemical products, such as poisons, lye, etc, is difficult within the home, especially when adolescents are present ${ }^{(7)}$.

The majority of adolescents interviewed had no previous history of attempted suicide. However, the percentage of recurrence was relatively high. Among such cases, the first attempt had occurred one or two years earlier in most cases. This pattern was also described in a previous study, which found a greater tendency toward a repeated suicide attempt within two years from the first. ${ }^{(31)}$ Regarding the method employed among the adolescents with a previous history of attempted suicide, the majority used exogenous intoxication. This finding is in agreement with a study carried out in the city of Londrina (state of Paraná, Brazil) involving 70 students between 12 and 24 years of age, which reported that the ingestion of medications was the most often employed method among those with a previous history ${ }^{(16)}$.

Family relations are commonly strongly associated to suicides among adolescents, including aspects such as family structure and relations between family members. ${ }^{(32)}$ Adolescents face different situations in the family setting that, when not well understood and analyzed, can lead to emotional imbalance, triggering an suicidal $\mathrm{act}^{(12)}$. In a study carried out with 24 female Israeli adolescents in an emergency ward following self-intoxication of low lethality, the participants were 
from families with a lifestyle characterized as "control without affection", in which the parents valued care with less affection and greater control ${ }^{(33)}$. Therefore, there is a need to address familial aspects in studies on suicide attempts among adolescents.

Families need to be included in health care directed at adolescents, considering the family as the most important social cell for adolescents, like any human being ${ }^{(34)}$. It is necessary to include families in aspects related to the detection of and reduction in risk factors associated to suicide attempts by adolescents and families should be incorporated in the therapy of youths with this behavior ${ }^{(35)}$. Educative activities should be implanted in the support of families to the assimilation of changes among adolescents in their process of individualization, providing open family support ${ }^{(7,36)}$.

The present study was limited to acquiring data from a hospital setting. However, one must recognize the likely large number of under-notifications, as only more serious cases end up leading to hospitalization. Moreover, prejudices and cultural-historic influence should also be taken into consideration. With adolescents, notification barriers may be more accentuated, as self-destructive acts are denied and even hidden by the family due to feelings of guilt and/or shame ${ }^{(31)}$.

Suicide is stigmatized and surrounded by taboos. In some societies, when a death is said to have been brought about by suicide, the subject is avoided or prohibited. According to the American Academy of Pediatrics, the population generally tends to deny this severe attitude as part of the natural flow of life, especially when it occurs among adolescents ${ }^{(37)}$. Nonetheless, it is currently known that adolescents are especially vulnerable and react with suicidal attitudes in response to serious conflicts.

\section{CONCLUSIONS}

The management of suicidal behavior in adolescents by healthcare professionals is complex and involves the interaction of ethical, religious, moral, cultural and circumstantial aspects. Thus, the study of this topic is important. The results of the present study reveal that female adolescents belong to a group with peculiar characteristics and there is a need for discussions regarding programs, treatment and prevention measures for this vulnerable group. It is fundamental to establish strategies for addressing this problem in both basic and specialized healthcare.

As part of the measures needed to reduce the rate of exogenous intoxication, it is important to implement a rigorous control of the informal marketing of pesticides as well as the prescription and distribution of medications, especially psychotropic drugs. There is a need for further studies on this issue involving particular populations, such as that addressed in the present study, with a focus on the family system.

\section{REFERENCES}

1. Abasse MLF, Oliveira RC, Silva TC, Souza ER. Análise epidemiológica da morbimortalidade por suicídio entre adolescentes em Minas Gerais, Brasil. Ciênc. Saúde Colet. 2009;14(2):407-416.

2. Peres F, Rosenburg CP. Desvelando a concepção de adolescência/adolescente presente no discurso da saúde pública. Saúde Soc. 1998;7(1):53-86.

3. Schimtz M, Torres JB, Soares PFB. Tentativa de suicídio por autoenvenenamento: um estudo sobre 684 casos. Revista ABP-APAL 1992;14(2):63-66.

4. Cassorla R. Jovens que tentam suicídio características demográficas e sociais: um estudo comparativo com jovens normais e com problemas mentais (I). J. Bras. Psiquiatr. 1984;33(1):3-12

5. Meneghel SN, Victora CG, Faria NMX, Carvalho LA, Falk JW. Características epidemiológicas do suicídio no Rio Grande do Sul. Rev. Saúde Publica. 2004;38(6):804-810.

6. Souza LDM, Silva RA, Jansen K, Kuhn R, Horta BL, Pinheiro RT. Suicidal ideation in adolescents aged 11 to 15 years: prevalence and associated factors. Rev. Bras. Psiquiatr. 2010;32(1):37-41.

7. Avanci RC, Pedrão JL, Costa Júnior ML. Perfil do adolescente que tenta suicídio em uma unidade de emergência. Ver. Bras. Enferm. 2005;58(5):535-539.

8. Krug EG, Dahlberg LL, Mercy JA, Zwi AB, Lorenzo R, editors. World report on violence and health. Geneva: World Health Organization; 2002.
9. Stefanello S, Cais CFS, Mauro MLF, Freitas GVS, Botega NJ. Gender differences in suicide attempts: preliminary results of the multisite intervention study on suicidal behavior (SUPRE-MISS) from Campinas, Brazil. Rev. Bras. Psiquiatr. 2008;30(2):139-143.

10. Alacán PL, Aliño SM, Álvarez ACZ, Acarez PR, Bandera RA, Bello M. Manual de prácticas clínicas para la atención integral a la salud en la adolescencia. Ciudad de La Habana: MINISAP; 2002.

11. Rogers JH, Osborn HH, Pousada L. Enfermagem de emergencia. Porto Alegre: Ates Médicas; 1992.

12. Gutiérrez MA, Fernández SGM, Jiménez MM, Gutiérrez JMA, Tamayo OD. Modificación de conocimientos sobre conducta suicida en adolescentes y adultos jóvenes con risco. Medisan 2009[cited 2011 Jan 30];13(1). Available from: http://bvs.sld.cu/revistas/san/vol13_1_09/san05109.htm.

13. Souza ER, Minayo MCS, Malaquias JV. Suicide among young people in selected Brazilian State capitals. Cad. Saude Publica 2002;18(3):673-683.

14. Cassorla RMS. Jovens que tentam suicídio e narcisismo destrutivo: dois modelos compreensivos do fenômeno suicida. Medicina (Ribeirão Preto) 2005;38(1):45-48.

15. Macente LB, Santos EG, Zandonade E. Tentativas de suicídio e suicídio em município de cultura Pomerana no interior do estado do Espírito Santo. J. Bras. Psiquiatr. 2009;58(4):238-244.

16. Marcondes Filho W, Mezzaroba L, Turini CA, Koike A, 
Motomatsu Junior A, Shibayama EEM, Fenner FLS. Tentativas de suicídio por substâncias químicas na adolescência e juventude. Adolesc. Latinoam. 2002;3(2).

17. Prieto D, Tavares M. Fatores de risco para suicídio e tentativa de suicídio: incidência, eventos estressores e transtornos mentais. J. Bras. Psiquiatr. 2005;54(2):146-154.

18. Romão MR, Vieira LJES. Tentativas suicidas por envenenamento. RBPS 2004;17(1):14-20.

19. World Health Organization - WHO/OMS. Available from: URL: http://www.who.int/en/.

20. American Association of Suicidology. USA Suicide: 2004 Official Final Data. Washington; 2006. Available from URL: http://www.suicidology.org/associations/1045/ files/2004datapgv1.pdf.

21. Mello-Santos C, Bertolote JM,Wang YP. Epidemiology of suicide in Brazil (1980 - 2000): characterization of age and gender rates of suicide. Rev. Bras. Psiquiatr. 2005;27(2):131-134.

22. Aponte RR. El suicidio en el adolescente factores epidemiológicos y etiológicos. Arch. Venez. Psiquiatr. Neurol. 1983;29(61):9-17.

23. Shain BN. Suicide and suicide attempts in adolescents. Pediatrics 2007; 120(3):669-677

24. Margonato FB, Thomson Z, Paoliello MMB. Acute intentional and accidental poisoning with medications in a southern Brazilian city. Cad. Saúde Pública 2009;25(4):849-856.

25. Lovisi GM, Santos SA, Legay L, Abelha L, Valencia E. Análise epidemiológica do suicídio no Brasil entre 1980 e 2006. Rev. Bras. Psiquiatr. 2009:31(Supl II):S86-93.

26. Lopes FH. Medicina, educação e gênero: as diferenciações sexuais do suicídio nos discursos médicos do século XIX. Educar 2007;29:241-257.
27. Feijó RB, Salazar CC, Bozko MP, Bozko MP, Candiago $\mathrm{RH}$, Ávila $\mathrm{S}$ et al. $\mathrm{O}$ adolescente com tentativa de suicídio: características de uma amostra de 13 a 20 anos atendida em emergência médica. J. Bras. Psiquiatr. 1996;45(11):657-64.

28. Bahls SC. Aspectos clínicos da depressão em crianças e adolescentes. J. Pediatr. 2002;78(5):359-366.

29. Bortoletto ME, Bochner R. Impacto dos medicamentos nas intoxicações humanas no Brasil. Cad. Saúde Pública 1999;15(4):859-869.

30. Bochner R. Perfil das intoxicações em adolescentes. Cad. Saúde Pública 2006;22(3):587-595.

31. Cassorla RMS, Smeke ELM. Autodestruição humana. Cad. Saúde Pública 1994;10(1):61-73.

32. Ballone GJ. Suicídio na Adolescência. [citado em 30 Jan 2011] In: PsiqWeb: 2003. Disponível em: http:www.virtualpsy.org/infantil/suicidio.html.

33. Diamond GM, Didner H, Waniel A, Priel B, Asherov J, Arbel S. Perceived parental care and control among israeli female adolescents presenting to emergency rooms after self-poisoning. Adolescense 2005; 40(138).

34. Freitas MLV. Razões para Tentativas Suicidas em Adolescentes: desafio para a educação em saúde [dissertação]. Fortaleza (CE): Universidade de Fortaleza; 2005.

35. Pavez P, Santander N, Carranza J, Vera-Villarroel P. Factores de riesgo familiares asociados a la conducta suicida en adolescentes con trastorno depresivo. Rev. méd. Chile 2009; 137:226-233.

36. Figueroa IV, Montoya RQ, Gallegos NG. El papel de la familia en el intento suicida del adolescente: cartas al editor. Salud Publ Mex 2005;47(1):1-2.

37. American Academy of Pediatrics. Suicide and suicide attempts in adolescents. Pediatrics 2000;105(4):871-874. 